\title{
Attenuation of Atherosclerosis by 3,4-Dihydroxy- Hydrocinnamic Acid in Rabbits by Partial Inhibition of ACAT
}

\author{
Mi-Ran Lee ${ }^{1}$, Jae-Hoon Choi $^{2}$, Young Yang ${ }^{3}$, Ki Sook Oh ${ }^{3}$, Tae-Sook Jeong ${ }^{4}$, Chul-Ho Lee ${ }^{4}$, \\ Goo Taeg $\mathrm{Oh}^{5}$ \\ ${ }^{1}$ Department of Biomedical Laboratory Science, Jungwon University, Goesan 28024, Korea \\ ${ }^{2}$ Department of Life Science, College of Natural Sciences, Research Institute of Natural Sciences, Hanyang University, Seoul 04763, Korea \\ ${ }^{3}$ Research Center for Women's Disease, Department of Life Science, Sookmyung Women’s University, Seoul 04310, Korea \\ ${ }^{4}$ Industrial Bio-materials Research Center, Korea Research Institute of Bioscience and Biotechnology (KRIBB), Daejeon 34141, Korea \\ ${ }^{5}$ Department of Life Sciences, Ewha Womans University, Seoul 03760, Korea
}

\section{토끼에서 ACAT 억제에 의한 3,4-다이하이드록시 하이드로시나믹산의 동맥경화 완화 효과}

\author{
이미란 ${ }^{1}$, 최재훈 ${ }^{2}$, 양 영 ${ }^{3}$, 오기숙 ${ }^{3}$, 정태숙 ${ }^{4}$, 이철호 ${ }^{4}$, 오구택 ${ }^{5}$ \\ ${ }^{1}$ 중원대학교 의료보건대학 임상병리학과, ${ }^{2}$ 한양대학교 자연과학연구소 자연과학대학 생명과학과, ${ }^{3}$ 숙명여자대학교 생명과학과 여성질환연구센터, \\ 한국생명공학연구원 산업바이오소재연구센터, ${ }^{5}$ 이화여자대학교 생명과학과
}

\begin{abstract}
Polyphenols have been reported to have beneficial effects on cardiovascular disease. A polyphenolic compound, 3,4-dihydroxy-hydrocinnamic acid (3,4-DHHCA), has been shown to have antioxidative and antitumorigenic activities. However, the effect of 3,4-DHHCA on atherosclerosis is still unknown. Herein, we investigated the effects of 3,4-DHHCA on atherosclerosis in New Zealand White rabbits. Broad and fused fatty streak lesions were found in rabbits fed with high-cholesterol diet for 8 weeks. Administration of 3,4-DHHCA reduced atherosclerotic lesion formation and lesional accumulation of macrophage in rabbits fed with cholesterol diet without systemic or local toxicity. Hepatic acyl-coenzyme A: cholesterol acyltransferase (ACAT) activity was decreased after treatment with 3,4-DHHCA by $22 \%$ in cholesterol diet-fed rabbits compared with the control group. These results indicate that 3,4-DHHCA had antiatherogenic effects in rabbits, possibly by partial inhibition of ACAT.
\end{abstract}

Key words: Atherosclerosis, 3,4-dihydroxy-hydrocinnamic acid, Animal models, Acyl-CoA:cholesterol acyltransferase, High density lipoprotein

This is an Open Access article distributed under the terms of the Creative Commons Attribution Non-Commercial License (http://creativecommons.org/licenses/by-nc/4.0) which permits unrestricted non-commercial use, distribution, and reproduction in any medium, provided the original work is properly cited.

Copyright @ 2016 The Korean Society for Clinical Laboratory Science. All rights reserved.
Corresponding author: Goo Taeg Oh Department of Life Sciences, Ewha Womans University, 52 Ewhayeodae-gil, Seodaemun-gu, Seoul 03760, Korea Tel: $82-2-3277-4128$

Fax: 82-2-3277-3760 E-mail: gootaeg@ewha.ac.kr

Received: October 25, 2016 Revised: November 16, 2016 Accepted: November 18, 2016

\section{Introduction}

Atherosclerosis is a chronic inflammatory disease of the aorta characterized by accumulation of inflammatory cells in the subintimal space [1]. Hyperlipidemia, a major risk factor of atherosclerosis, stimulates the inflammatory process by inducing prolonged retention and modification of lipids in the subintimal space [2]. Blood monocytes recruited by inflam- 
matory signals take up modified lipids and differentiate to foam cells, the prominent cell type in atherosclerosis [3]. Although the foam cells mostly originate from recruited monocyte/macrophages, recent studies showed that smooth muscle cells could also take up lipids and differentiate to foam cells [4-7].

These atherosclerotic processes are controlled by two key enzymes that regulate cholesterol metabolism, 3-hydroxy-3methylglutaryl-CoA (HMG-CoA) reductase and acyl-CoA: cholesterol acyltransferase (ACAT) [8,9]. HMG-CoA reductase is the rate-controlling enzyme in cholesterol production. Since inhibition of HMG-CoA reductase can decrease the plasma lipid level, statins such as atorvastatin, simvastatin, rosuvastatin, and lovastatin have been widely used as therapeutic agents for atherosclerosis [9,10]. ACAT is an intracellular enzyme that converts cholesterol to cholesteryl esters (CEs). CEs produced by ACAT1 accumulate in macrophages leading to foam cell formation [11]. ACAT catalyzes cholesterol esterification and plays important roles in lipoprotein assembly, dietary cholesterol absorption, and intracellular cholesterol metabolism [12]. Thus, this enzyme is thought to be responsible for foam cell formation and the subsequent progression of atherosclerosis. Ironically, ACAT deficiency in macrophages exacerbates atherosclerosis in mice due to the toxicity of free cholesterol that accumulates in the cytoplasm [13], whereas partial inhibition of ACAT decreases atherosclerosis without toxicity [11]. Therefore, a compound that can partially inhibit HMG-CoA reductase and/or ACAT might be considered a therapeutic candidate for atherosclerosis.

Previously, polyphenols have been shown to have beneficial effects on atherosclerosis through cholesterol efflux capacity, and antioxidative and anti-inflammatory activities [14-16] . 3,4-dihydroxy-hydrocinnamic acid (3,4-DHHCA), a polyphenolic compound, has been reported to have antioxidative and antitumorigenic activities [17,18]. Moreover, in a previous study 3,4-DHHCA reduced plasma lipid levels through inhibition of HMG-CoA reductase in rats fed a highcholesterol diet, but ACAT was not inhibited by 3,4-DHHCA [19]. Considering its inhibitory effect on HMG-CoA reductase, 3,4-DHHCA may attenuate the formation of atherosclerotic lesions. Nevertheless, the function of 3,4-DHHCA in the pathogenesis of atherosclerosis is yet to be defined. In this study, we show antiatherogenic activity of 3,4-DHHCA in rabbits. Interestingly, in this atherosclerosis model, 3,4-DHHCA did not decrease the plasma total cholesterol level but partially inhibited ACAT activity, suggesting its therapeutic potential for the treatment of atherosclerosis.

\section{Materials and Methods}

\section{Animal models and drug administration}

New Zealand White (NZW) rabbits aged 3 months and weighing between 2.3 and $2.5 \mathrm{~kg}$ were used in these experiments. The rabbits were divided into two groups ( $n=10$ per group), which were provided with a $1 \%$ cholesterol diet (RC4, Oriental Yeast Co. Ltd., Tokyo, Japan; controls) or a 1\% cholesterol diet containing $0.1 \%$ lovastatin or $0.05 \% 3,4$-DHHCA (Sigma, St Louis, MO, USA) for 8 weeks. All rabbits were individually caged and maintained in a controlled facility at $20 \pm 2^{\circ} \mathrm{C}$, relative humidity of $55 \pm 5 \%$, and a strict 12 -hr light/dark cycle.

\section{Evaluation of atherosclerosis}

After blood collection all rabbits were anesthetized with thiopental sodium (Choongwae Pharma Co., Seoul, Korea) and sacrificed by exsanguination from the femoral artery. Immediately after opening the thoracic cavity the aorta was excised and adventitial tissue grossly adhering to the aorta was removed. The aorta was dissected longitudinally and separated into three portions. The first portion, a $1-\mathrm{cm}$ segment proximal to the outlet of the first intercostal artery, was snap-frozen in liquid nitrogen until further processing. The second portion, a segment between the first and the second intercostal artery, was routinely processed, paraffinembedded and used for histologic examination. The third portion, a segment between the second and the seventh intercostal arteries, was fixed in 10\% neutral buffered formalin for 1 day and then placed in absolute propylene glycol for $2 \mathrm{~min}$ and stained with oil red-O for $4 \mathrm{hr}$. After washing, the extent of the oil red O-positive area was measured and expressed as a percentage of the internal 
surface using a computer-assisted morphometry system (Image Pro Plus).

\section{Immunohistochemistry}

The second portion, the paraffin-embedded segment between the first and the second intercostal artery, was cut into $6-\mu \mathrm{m}$ sections and two serial sections were obtained every $240 \mathrm{~mm}$. To observe the sections by light microscopy, the first section was stained with hematoxylin and eosin. To identify the intimal macrophages, the second serial section was immunostained with commercial mouse antibodies to rabbit macrophages (1:500 dilution; DAKO, Carpinteria, CA, USA) using an avidin/biotin/horseradish peroxidase complex system (Novocastra Laboratories Ltd., Newcastle upon Tyne, UK) in accordance with the manufacturer's instructions. After immunostaining, the extent of the atherosclerotic lesions in each group was evaluated by a semiquantitative method. A minimum of 20 antibody stained sections for each rabbit were examined and the stage of each lesion was graded from 0 to 3 according to the relative content of intimal macrophage/foam cells ( $0=$ normal intima without any subendothelial monocyte/macrophage, 1=isolated monocytes/ macrophages in the subendothelial space, 2=single monolayer of monocytes/macrophages underneath the endothelium, $3=$ presence of multiple layers of monocytes/macrophages as well as transitional and more advanced lesions). The index of the atherosclerotic lesions in each group was obtained from the sum of the stage numbers divided by the number of sections examined.

\section{Determination of ACAT activity}

ACAT activity was determined using freshly prepared hepatic microsomes according to previously reported protocols [20,21]. Briefly, hepatic microsomes were prepared by ultracentrifugation using Beckman L8-M (Palo Alto, CA) and SW55.1 rotor. $10 \mu \mathrm{g}$ of the microsomal fraction and $6 \mu \mathrm{g}$ of cholesterol substrate were preincubated at $37^{\circ} \mathrm{C}$ for $30 \mathrm{~min}$ and the reaction was initiated by adding $20 \mu \mathrm{L}$ of $5.62 \mathrm{nmol}$ of $\left[{ }^{14} \mathrm{C}\right]$-oleoyl-CoA (specific activity $=56 \mathrm{mCi} / \mathrm{mmol}$; Life Sciences, MA, USA). Finally, the supernatant was subjected to scintillation counting. The ACAT activity are expressed as picomol of cholestryl oleate synthesized per min per mg protein.

\section{Statistical analysis}

Results were expressed as mean $\pm \mathrm{SD}$. The two-tailed Student's t-test was used to compare means of different groups and a $p$-value less than 0.05 was considered to be statistically significant.

\section{Results}

\section{3,4-DHHCA did not decrease total plasma cholesterol level in rabbits fed a high-cholesterol diet}

The body weights of all rabbits in the control and 3,4-DHHCA groups increased progressively during the experimental period, and there were no significant differences between each group (data not shown). Furthermore, there were no significant lesions in other parenchymal organs of the 3,4-DHHCA group (data not shown). After 8 weeks of a high-cholesterol diet, the plasma total cholesterol levels had dramatically increased in all rabbit groups. The plasma total cholesterol levels of the different groups did not differ significantly during the experimental period (Fig. 1A). The triglyceride (Fig. 1B) and HDL cholesterol (Fig. 1C) levels of the 3,4-DHHCA-supplemented group were also not significantly different from those of the control group.

\section{3,4-DHHCA attenuates atherosclerosis in rabbits fed a high-cholesterol diet}

In high-cholesterol diet fed rabbits, the fatty streak lesions of the ascending and descending thoracic aorta in each group were easily identified by staining with oil red $\mathrm{O}$. Broad and fused fatty streak lesions were evident in control rabbits fed the $1 \%$ cholesterol diet alone, whereas only sparse welldemarcated, 0.5- to 3-mm-diameter plaques were observed in the 3,4-DHHCA-supplemented groups (Fig. 2A). The percentage area occupied by atherosclerotic lesions on the inner surface between the second and seventh intercostal arteries (the third portion) was significantly lower in the 0.05\% 3,4-DHHCA-supplemented group (14.9 $\pm 6.8 \%)$ compared to the control group $(63.5 \pm 8.2 \%, p<0.001)$ (Fig. 2B). 
A

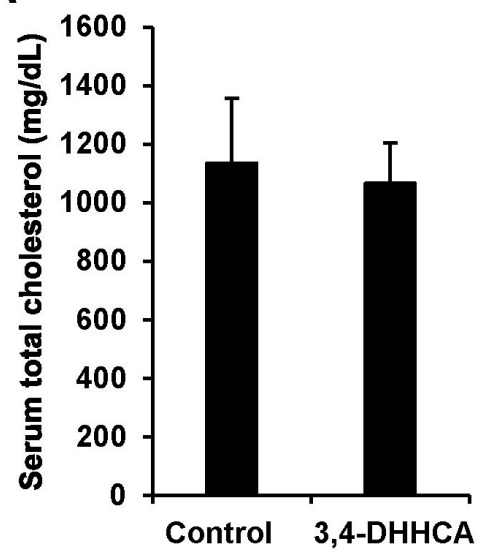

B

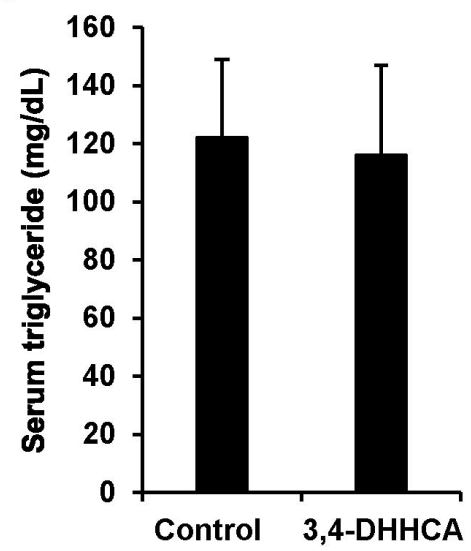

C

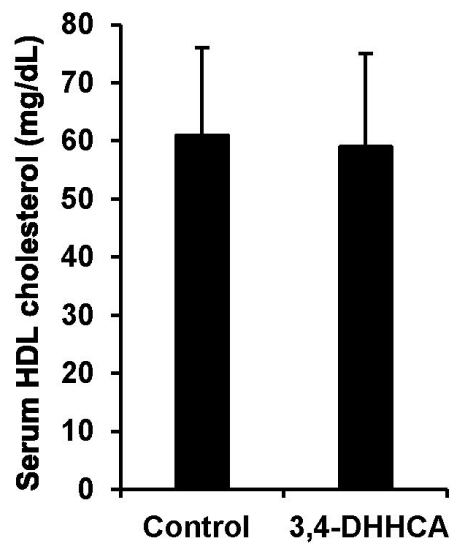

Fig. 1. Effects of 3,4-DHHCA on serum lipid levels in rabbits fed a high cholesterol diet for 8 weeks. The serum levels of total cholesterol $(\mathrm{A})$, triglyceride (B) and HDL cholesterol (C) were measured in 3,4-DHHCA-treated and control rabbits fed a high cholesterol diet for 8 weeks.

A

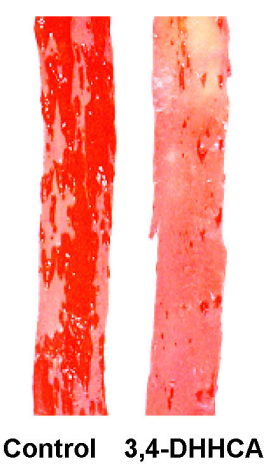

B

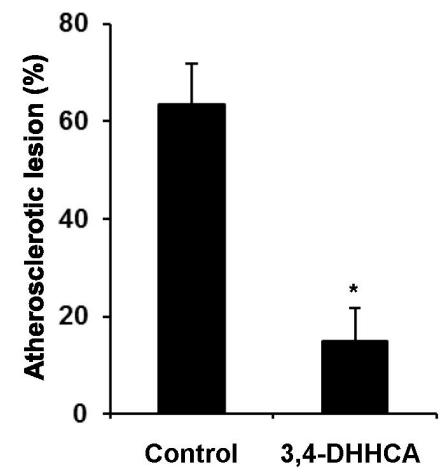

Fig. 2. 3,4-DHHCA attenuates atherosclerotic plaque formation in rabbits fed a high cholesterol diet for 8 weeks. (A) Gross photographs of oil red-O stained aorta between the second and seventh intercostal arteries (the third portion). (B) A graph of atherosclerotic lesion size expressed as a percentage of the oil red- $O$ positive area in intimal surface of aorta. Bars represent standard deviations. ${ }^{*}$ Indicates statistical significance $(p<0.001)$.

\section{3,4-DHHCA decreases macrophage content of} atherosclerotic lesion in rabbits fed a high-cholesterol diet

Histologically, staining of the second portion, the aortic segment between the first and the second intercostal arteries, with hematoxylin and eosin revealed intimal thickening, mainly due to accumulation of foam cells, infiltration and proliferation of smooth muscle cells in the intima, and deposition of extracellular matrix substances. The intimal thickening was reduced in the 3,4-DHHCA-supplemented groups compared to the control group (Fig. 3A, left panel). By

immunohistochemistry using antibody against macrophages, massive accumulation of macrophages was observed in the atherosclerotic intima of the control group, but decreased in the 3,4-DHHCA-treated group (Fig. 3A, right panel). Semiquantitative analysis of the intimal thickening of each group according to subendothelial macrophage content showed significantly lower scores in the 3,4-DHHCAsupplemented group than in the control group $(p<0.001)$ (Fig. 3B). These results indicate that 3,4-DHHCA attenuated the accumulation of foamy macrophages in atherosclerotic lesions, suggesting its therapeutic potential.

\section{3,4-DHHCA partially inhibits ACAT activity in rabbits fed a high-cholesterol diet}

Although 3,4-DHHCA inhibited HMG-CoA reductase in a previous study [18], total plasma cholesterol levels were not reduced by 3,4-DHHCA in rabbits of our study. However, atherosclerotic lesion formation and macrophage infiltration were significantly decreased by 3,4-DHHCA. These results prompted us to investigate the effect of 3,4-DHHCA on ACAT activity, another important cholesterol metabolizing enzyme. Hepatic ACAT activities were significantly decreased in the 3,4-DHHCA group compared to the control group for rabbits (Fig. 4). In addition, lovastatin, a known HMG-CoA reductase inhibitor, also reduced ACAT activity in rabbits (Fig. 4). Thus, although ACAT activity was not inhibited by 3,4-DHHCA in a rat model, 3,4-DHHCA reduced hepatic ACAT activity in rabbits. 
A
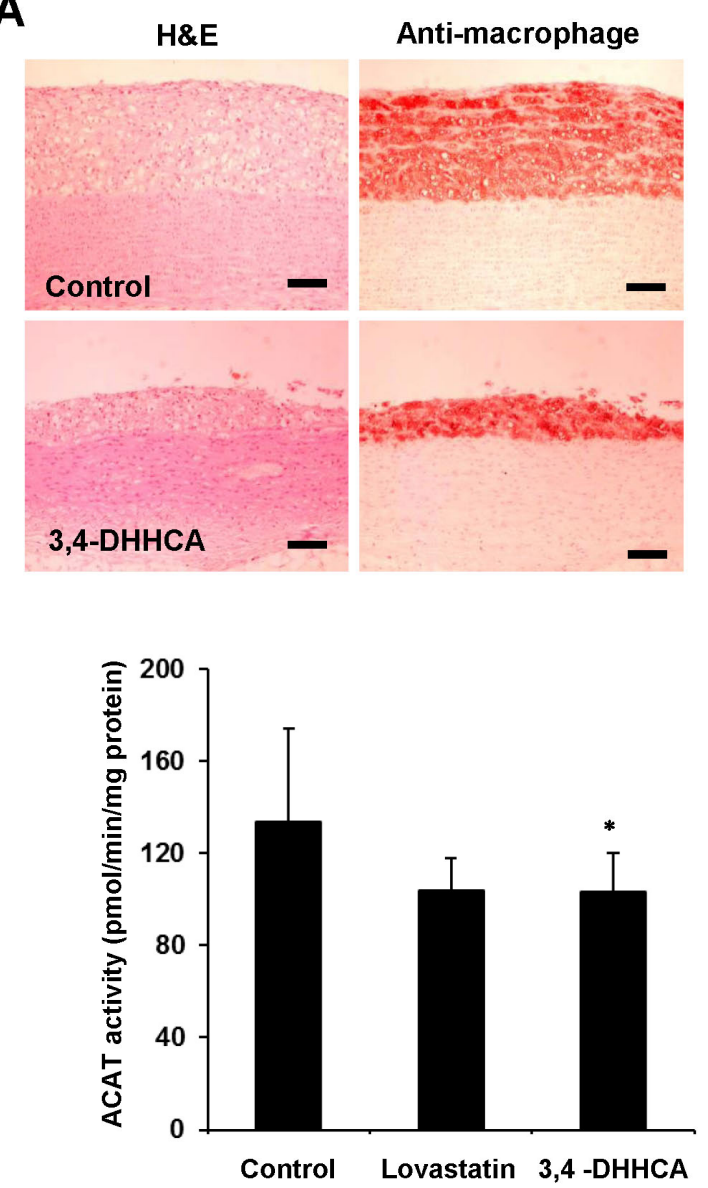

Fig. 4. Effect of 3,4-DHHCA on hepatic microsomal ACAT enzymatic activities in high cholesterol-fed rabbits. *Significantly different between groups $(p<0.05)$.

\section{Discussion}

A previous study demonstrated the lipid lowering activity of 3,4-DHHCA in a rat model. However, the rat model is highly resistant to hyperlipidemia and atherosclerosis and does not develop atherosclerosis, even with a highcholesterol diet [22]. Therefore, to determine the effect of 3,4-DHHCA on hyperlipidemia and atherosclerosis, we used New Zealand White rabbits in this study.

HMG-CoA reductase is best known for catalyzing a rate-limiting step in cholesterol biosynthesis and its inhibitors are the most effective class of drugs for lowering serum cholesterol concentrations [9]. A previous report showed that 3,4-DHHCA acts as inhibitor of HMG-CoA reductase in a rat model [19]. However, in this study, the serum levels of total cholesterol, triglyceride and HDL cholesterol were not

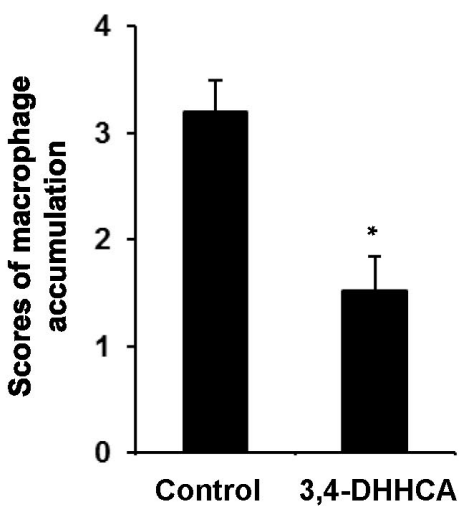

Fig. 3. 3,4-DHHCA reduces atherosclerotic intimal thickening and macrophage accumulation in rabbits fed a high cholesterol diet for 8 weeks. (A) Representative cross-sections of hematoxylin and eosin (H\&E) staining (left panel) and immunostaining for macrophage antibody (right panel) on the aortic segment between the first and the second intercostal arteries. Bars represent $95 \mu \mathrm{m}$. (B) Quantification of macrophage content in atherosclerotic lesions in the two groups. *Indicates statistical significance $(p<0.01)$.

significantly different between 3,4-DHHCA-treated rabbits and controls. Considering the previous report, these results were unexpected. Further study is required to elucidate this difference among animal models.

Based on previous studies showing that ACAT inhibitors prevented atherosclerotic lesion formation in various animal models [23,24], the antiatherosclerotic potential of ACAT inhibitors, such as the drug pactimibe, was investigated in human patients. However, treatment with pactimibe was not effective for the treatment of atherosclerosis in humans [25]. Furthermore, complete deficiency of macrophage ACAT1 exacerbated plaque inflammation, leading to enhanced atherosclerosis, which was attributed to cytotoxicity induced by the increased free cholesterol [13]. Accumulation of free cholesterol induces stress on the endoplasmic reticulum and the formation of cholesterol crystals, leading to inflammasome activation [26]. Thus, proper control of cytosolic free cholesterol levels is crucial to achieving desirable antiatherosclerotic effects using ACAT inhibitors. Recently, partial inhibition of ACAT was shown to be effective for decreasing the atherosclerotic lesion formation without toxic side effects $[27,28]$. Therefore, in spite of the failure of clinical trials with ACAT inhibitor, efforts to find new partial ACAT inhibitors with low toxicity should be continued.

Collectively, our data show that 3,4-DHHCA attenuated atherosclerotic lesion formation in rabbits without obvious toxicity and partially inhibited ACAT activity. These results suggest the therapeutic potential of 3,4-DHHCA in the clinical treatment of atherosclerosis. 


\section{요 약}

폴리페놀 성분은 심혈관질환에서 좋은 효과를 나타낸다고 보고 되고 있다. 폴리페놀성 화합물인 3,4-다이하이드록시 하이드로시 나믹산은 항산화 활성과 항암 활성을 나타낸다고 보고되었다. 이 연구의 목적은 3,4-다이하이드록시 하이드로시나믹산이 항동맥 경화 효과를 나타내는지를 뉴질랜드 흰 토끼에서 평가하는 것이다. 8주동안 고콜레스테롤 식이를 급여한 대조그룹 토끼의 광범위한 동맥 부위에서 동맥경화 초기병변이 형성되었다. 반면에 고콜레스 테롤 식이를 급여하면서 3,4-다이하이드록시 하이드로시나믹산 을 투여한 토끼에서는 대조 그룹의 토끼에 비해 동맥경화 병변 형 성이 감소하였고, 병변 내로 침윤한 대식세포의 양도 감소하였다. 이러한 3,4-다이하이드록시 하이드로시나믹산의 효과에서 전신 적으로나 국부적으로 독성이 관찰되지 않았다. 간의 아실-코엔자 임 A: 콜레스테롤 아실트렌스페라제 활성이 고콜레스테롤 식이를 급여하면서 3,4-다이하이드록시 하이드로시나믹산을 투여한 토 끼에서 대조 그룹의 토끼에 비해 $22 \%$ 감소하였다. 이러한 연구 결 과는 3,4-다이하이드록시 하이드로시나믹산이 토끼에서 아실-코 엔자임 A: 콜레스테롤 아실트렌스페라제를 억제함으로써 항동맥 경화 효과를 나타낸다는 것을 증명해 준다.

\section{Acknowledgements: None}

Funding: This work was supported by the Korean Society of Lipidology and Atherosclerosis (2012), Basic Science Research Program through the National Research Foundation of Korea (NRF) funded by the Ministry of Science, ICT \& Future Planning (NRF-2012R1A1A3014267) and the Bio \& Medical Technology Development Program of the NRF (MSIP, No. 2015M3A9B60 29138) by the Korea government.

Conflict of interest: None

\section{References}

1. Hansson GK, Libby P. Inflammation and immunity in diseases of the arterial tree: players and layers. Circ Res. 2015;116: 307-311.

2. Hansson GK, Libby P. The immune response in atherosclerosis: a double-edged sword. Nat Rev Immunol. 2006;6:508-519.

3. Hilgendorf I, Swirski FK, Robbins CS. Monocyte fate in atherosclerosis. Arterioscler Thromb Vasc Biol. 2015;35:272279.

4. Allahverdian S, Chehroudi AC, McManus BM, Abraham T, Francis GA. Contribution of intimal smooth muscle cells to cholesterol accumulation and macrophage-like cells in human atherosclerosis. Circulation. 2014;129:1551-1559.

5. Rong JX, Shapiro M, Trogan E, Fisher EA. Transdifferentiation of mouse aortic smooth muscle cells to a macrophage-like state after cholesterol loading. Proc Natl Acad Sci U S A. 2003;100: 13531-13536.

6. Vengrenyuk Y, Nishi H, Long X, Ouimet M, Savji N, Martinez FO, et al. Cholesterol loading reprograms the microRNA-143/ 145-myocardin axis to convert aortic smooth muscle cells to a dysfunctional macrophage-like phenotype. Arteriosclerosis Thrombosis Vasc Biol. 2015;35:535-546.

7. Feil S, Fehrenbacher B, Lukowski R, Essmann F, SchulzeOsthoff K, Schaller M, et al. Transdifferentiation of vascular smooth muscle cells to macrophage-like cells during atherogenesis. Circ Res. 2014;115:662-667.

8. Rudel LL, Lee RG, Cockman TL. Acyl coenzyme A: cholesterol acyltransferase types 1 and 2: structure and function in atherosclerosis. Curr Opin Lipidol. 2001;12:121-127.

9. Pedersen TR. The success story of LDL cholesterol lowering. Circ Res. 2016;19;118:721-731.

10. Lee JS, Bok SH, Park YB, Lee MK, Choi MS. 4-Hydroxycinnamate lowers plasma and hepatic lipids without changing antioxidant enzyme activities. Ann Nutr Metab. 2003;47:144-151.

11. Kusunoki J, Hansoty DK, Aragane K, Fallon JT, Badimon JJ, Fisher EA. Acyl-CoA:cholesterol acyltransferase inhibition reduces atherosclerosis in apolipoprotein E-deficient mice. Circulation. 2001;103:2604-2609.

12. Buhman KF, Accad M and Farese RV. Mammalian acyl-CoA: cholesterol acyltransferases. Biochim Biophys Acta. 2000;1529: 142-154.

13. Fazio S, Major AS, Swift LL, Gleaves LA, Accad M, Linton MF, et al. Increased atherosclerosis in LDL receptor-null mice lacking ACAT1 in macrophages. J Clin Invest. 2001;107:163-171.

14. Wu C, Luan H, Zhang X, Wang S, Zhang X, Sun X, et al. Chlorogenic acid protects against atherosclerosis in ApoE-/mice and promotes cholesterol efflux from RAW264.7 macrophages. PLoS One. 2014; 4:e95452.

15. Noguchi N, Niki E. Phenolic antioxidants: a rationale for design and evaluation of novel antioxidant drug for atherosclerosis. Free Radic Biol Med. 2000;28:1538-1546.

16. Xu ZR, Li JY, Dong XW, Tan ZJ, Wu WZ, Xie QM, et al. Apple polyphenols decrease atherosclerosis and hepatic steatosis in ApoE-/- mice through the ROS/MAPK/NF- $\kappa B$ pathway. Nutrients. 2015;7:7085-7105.

17. Nardini M, D'Aquino M, Tomassi G, Gentili V, Di Felice M, Scaccini C. Inhibition of human low-density lipoprotein oxidation by caffeic acid and other hydroxycinnamic acid derivatives. Free Radical Biol Med. 1995;19:541-552.

18. Tanaka T, Kojima T, Kawamori T, Wang A, Suzui M, Okamoto K, et al. Inhibition of 4-nitroquinoline-1-oxide-induced rat tongue carcinogenesis by the naturally occurring plant phenolics caffeic, ellagic, chlorogenic and ferulic acids. Carcinogenesis. 1993;14:1321-1325.

19. Lee JS, Choi MS, Jeon SM, Jeong TS, Park YB, Lee MK, et al. Lipid-lowering and antioxidative activities of 3,4-di(OH)- cinnamate and 3,4-di(OH)-hydrocinnamate in cholesterol-fed rats. Clin Chim Acta. 2001;314:221-229.

20. Erickson SK, Shrewsbury MA, Brooks C, Meyer DJ. Rat liver ac- 
yl-coenzyme A:cholesterol acyltransferase: its regulation in vivo and some of its properties in vitro. J Lipid Res. 1980;21: 930-941.

21. Gillies PJ, Rathgeb KA, Perri MA, Robinson CS. Regulation of acyl-CoA:cholesterol acyltransferase activity in normal and atherosclerotic rabbit aortas: role of a cholesterol substrate pool. Exp Mol Pathol. 1986;44:329-339.

22. Russell JC, Proctor SD. Small animal models of cardiovascular disease: tools for the study of the roles of metabolic syndrome, dyslipidemia, and atherosclerosis. Cardiovascular Pathology. 2006;15:318-330.

23. Ikenoya M, Yoshinaka Y, Kobayashi H, Kawamine K, Shibuya K, Sato F. A selective ACAT-1 inhibitor, K-604, suppresses fatty streak lesions in fat-fed hamsters without affecting plasma cholesterol levels. Atherosclerosis. 2007;191:290-297.

24. Tauchi Y, Yoshimi A, Shirahase H, Sato J, Ito K, Morimoto K. Inhibitory effect of acyl-CoA:cholesterol acyltransferase inhibitor-low density lipoprotein complex on experimental atherosclerosis. Biol Pharm Bull. 2003;26:73-78.

25. Nissen SE, Tuzcu EM, Brewer HB, Sipahi I, Nicholls SJ, Ganz P. Effect of ACAT inhibition on the progression of coronary atherosclerosis. N Engl J Med. 2006;354:1253-1263.

26. Duewell P, Kono H, Rayner KJ, Sirois CM, Vladimer G, Bauernfeind FG. NLRP3 inflammasomes are required for atherogenesis and activated by cholesterol crystals. Nature. 2010; 464:1357-1361.

27. Rong JX, Blachford C, Feig JE, Bander I, Mayne J, Kusunoki J. ACAT inhibition reduces the progression of preexisting, advanced atherosclerotic mouse lesions without plaque or systemic toxicity. Arterioscler Thromb Vasc Biol. 2013;33:4-12.

28. Yoshinaka Y, Shibata H, Kobayashi H, Kuriyama H, Shibuya K, Tanabe S. A selective ACAT-1 inhibitor, K-604, stimulates collagen production in cultured smooth muscle cells and alters plaque phenotype in apolipoprotein E-knockout mice. Atherosclerosis. 2010;213:85-91. 